Original Research Report

\title{
The Correlation between Characteristics, Knowledge Early Marriage in Banjarmasin: The Impact on Reproductive Health and Prevention Strategy
}

\section{R. Topan Aditya Rahman ${ }^{1}$, Esti Yuandari ${ }^{2}$}

${ }^{1}$ Department of Information Technology, Faculty of Science and Technology, Sari Mulia University. Banjarmasin, Indonesia.

${ }^{2}$ Department of Health Promotion, Faculty of Health, Sari Mulia University. Banjarmasin, Indonesia.

Article History

Received:

27.02.2020

Revised:

29.02.2020

Accepted:

03.03.2020

*Corresponding Author:

R. Topan Aditya Rahman Email:

topanaditya85@gmail.com

This is an open access article, licensed under: $\mathrm{CC}-\mathrm{BY}-\mathrm{SA}$

(c) (i) (2)
Abstract: Problematic 10\% of teenagers by of aged 15-19 years in Indonesia have become mothers. In fact, getting pregnant at that age has many risks of childbirth complications. The purpose of this study is to determine the causal factors, the impact on reproductive health, and solutions to solving problems of early marriage. The design of this study used a qualitative method with a sample of couples who are married at a young age. Early marriage in the city of Banjarmasin is caused by one's own desires, intimate relationships, and getting pregnant first. Therefore, a strategic step to resolve the problem is through coaching youth and collaboration with the Office of Religious Affairs. Early marriage needs the support and active role of the community for reducing the cases.

Keywords: Adolescent, Effect of Early Marriage, Reproductive Health. 
R. Topan Aditya Rahman, Esti Yuandari.

The Correlation between Characteristics, Knowledge Early Marriage in Banjarmasin: The Impact on Reproductive Health and Prevention Strategy.

International Journal of Clinical Inventions and Medical Sciences, vol. 2, no. 1, pp. 15-19, March 2020. DOI: 10.36079/lamintang.ijcims-0201.77

\section{Introduction}

Indonesia is one of the countries with the largest population in the world of 261 million. This very large population is a serious threat to the people of Indonesia [1]. Thus, the Government of Indonesia must suppress population growth through strategies and policies. One of the strategies carried out by the Government at the moment is to form a National Population and Family Planning Agency $(\mathrm{BKKBN})$. BKKBN has a role in increasing the population growth rate which is carried out through a program consisting of Genre Program, which is the development of the Adolescent Reproductive Health Program. One derivative of the Genre Program is the maturity age of marriage [2].

In [3], it defines that marriage is an inner and physical bond between a man and woman as husband and wife to form a happy and eternal family (household) based on the Godhead of the One. According to [4], marriage is a door for the meeting of two hearts in the shelter of long-term life, in which some rights and obligations must be carried out by each party to get a decent, happy, harmonious life, and get descent. Marriage is very important for humans, because with marriage someone will get a balance of life both biologically, psychologically, and socially. So, it can be concluded that marriage is not merely a legality in living the life of husband and wife, but rather fostering inner and outer bonds in building family life.

The age limit for marriage is important, because marriage requires psychological maturity. The age of marriage that is too young can lead to an increase in divorce cases due to lack of awareness to be responsible in managing life as husband and wife. Early marriage is one of the social phenomena that still often occurs in Indonesia. The high number of early marriages that empower law enforcement in marriage law is still low, despite Law No. Law No. 1 of 1974 concerning Marriage, stipulates that the marital term limit for citizens for women is 16 years, but in terms of reproductive health of women, organs at that age are still not ripe for pregnancy [3]. At this early marriage many effects can be caused both socially, psychologically, and healthfully. But what we are discussing now is the impact on health, especially reproductive health issues. This is very important to review because reproductive health affects the quality of the fetus produced, and also affects the level of maternal health. Because the progress of a country can be implied by the maternal mortality rate.

Early marriage is a reason to minimize promiscuity. Adolescent social style now has deviated a lot from the existing norms, especially religious norms. Early marriage is considered as the right solution to overcome promiscuity. For instance, in the case of adultery, unwitting marriage only as an excuse to legalize sexual drive, without thinking about the impact caused by the young marriage. The results of a UNICEF study in Indonesia (2002), found that the incidence of marriages of children aged 15 years was around $11 \%$, while those who married at the right age of 18 years were around $35 \%$. From the results of the Ministry of Health of the Republic of Indonesia stated that $2.6 \%$ of marriages occur at the age of less than 15-19 years [5]. Whereas based on data from the Central Statistics Agency that marriages committed under the age of 16 are $11.23 \%$. South Kalimantan Province ranks first, with criteria for cases of early marriage at the age of $10-14$ years is $5.7 \%$ and aged $15-19$ years around $46 \%$ [6].

One factor in the occurrence of early marriage is caused by the rise of premarital sex cases carried out by adolescents today [7]. Much literature has been done to examine the factors that cause early marriage, but this case is still increasing. This is because the law on marriage is still low, for women at least 16 years old and men at least 19 years old. This causes the opportunity to legalize marriage and is influenced by local traditions. Based on this background, the proposer is interested in researching the factors that cause Early Marriage in the city of Banjarmasin. This study is expected to be a reference for the government in making policies or programs to reduce the case of young marriage in the city of Banjarmasin.

\section{Methods}

This study used a qualitative approach. Data gathered through in-depth interviews [8]. The population in this study were all early age couples with purposive sampling technique $[9,10]$.

The sample is divided into 2 categories of informants, namely:

- 3 main informants, and

- 2 triangulation informants. 
R. Topan Aditya Rahman, Esti Yuandari.

The Correlation between Characteristics, Knowledge Early Marriage in Banjarmasin: The Impact on Reproductive Health and Prevention Strategy.

International Journal of Clinical Inventions and Medical Sciences, vol. 2, no. 1, pp. 15-19, March 2020. DOI: 10.36079/lamintang.ijcims-0201.77

\section{Result and Discussion}

\subsection{Factor of Early Marriage}

Early marriage in the city of Banjarmasin is caused by several factors including:

a. Own desire

As stated by one of the main informants about the reasons for early marriage, the informant said that she married by her desire. The reason for the thought that she already had a boyfriend and often returned late at night while her boyfriend is visiting. Therefore, to avoid negative talk and perception from the surrounding community, the informant chose to get married at a young age, even though at that time her status was still a student.

b. Unwed Pregnancy

The main informant said that their relationship before marriage was free. Monitoring from parents is felt to be very lacking and the freedom given by parents to them, sometimes makes they have full freedom to express themselves. Gathering with peers is interesting for them without regard to moral values, social, and the negative effects of unhealthy relationships. As a result of promiscuity and a lack of control from parents, their free promiscuity has exceeded the limits of reasonableness and existing norms. As a result of this association, 2 of the 3 main informants did marriage at a young age due to unwanted pregnancy.

\subsection{Effect of Early Marriage}

When referring to the Law of the Republic of Indonesia No. 1 of 1974, a man is permitted to marry at the age of 19 , while a woman is 16 years old. However, marriages at that age cause controversies around reproductive health, especially for women such as an increased risk of sexual disease or sexual violence, many also assume that those who marry at a young age are not ready to face conflicts in the household, and this will have psychological effects.

Physically, adolescent women under the age of 20 cannot be said to be ideal for marriage. As revealed by a triangulation informant from the BKKBN of South Kalimantan Province who said that the ideal conditions for marriage are for women aged 21 years and men aged 25 years. According to the theory of a pregnant woman, less than 20 years of age can be detrimental to the health of the mother as well as the growth and development of the fetus due to the immature reproductive organs for pregnancy.

Complications in teenage pregnancies $<20$ years are higher than in healthy reproductive periods between 20-30 years. As revealed by the triangulation of informants in this study from the South Kalimantan Provincial Health Office who said that early marriage is very influential on the psychology of couples. A very young age causes emotions are still unstable, so it is feared it could lead to divorce. It also needs to be known that early marriage at the age of the child will cause various impacts. Among them are stunting children, malnutrition, maternal death, children born malnourished, and others. In line with the South Kalimantan Provincial Health Office, the same thing was expressed by the BKKBN which said that in terms of reproductive health itself, early marriage is very dangerous, where their reproductive organs are not yet ripe which correlates with maternal and child mortality rates. Based on what was experienced by one of the main informants in this study, where during the first pregnancy experienced severe bleeding so it must require medical treatment.

Psychologically, the adolescent mentality is also not ready to face various problems in marriage. As a result, many divorces occur at a young age and domestic violence. Married young are usually vulnerable to quarrels and divorce. Therefore, the social and emotional development of young people is still volatile so that it will cause a lot of disputes and quarrels. Although a person's maturity is not judged by age, young age is the biggest "rebellion" period compared to the adult age period. As stated by the informant, said that quarrels often occur because of their relatively young age, so that sometimes the words of divorce are often spoken, but the presence of children is the main factor they still maintain the household. This certainly becomes the basis that marriage does not only unite two different people in one marriage bond but needs to be seen from other aspects, namely physical and psychological readiness.

Other impacts caused by early marriage, apart from being seen physically and psychologically, will also affect the couple's economy. Young couples who get married early do not understand how to be responsible. They are still young in thought and still have much to learn about marriage. As stated by informants in this study about the difficulties they face after undergoing marriage. The problems faced by the informants are almost the same when viewed from an economic perspective which is 
their problem in running a household, with a low level of education making it difficult for them to get a decent income, assistance from parents is one additional source of daily life. Besides, early marriage also affects their education.

When adolescents get married early at a young age, their youth is disrupted. This is because they can no longer enjoy their freedom. However, the bound in marriage and new responsibilities. As stated by the informants in this study. Basically, they want to continue schooling both at the high school and university level, but it cannot be realized because they are more concerned with caring for their husbands and children, besides that they also earn less for their daily needs compared to continuing education.

\subsection{Prevention Strategies of Early Marriage}

Early marriage is an issue that is an important concern for all of us, i.e., the government, society, parents, and adolescents themselves as the main actors. Various ways have been carried out by the government both through programs and policies. Prevention strategies to overcome early marriage through various programs have been implemented, such as those carried out by the South Kalimantan Provincial Health Office through programs that have been implemented by providing public insights through counseling about reproductive health, the dangers of free sex and themes other issues related to adolescents.

In addition, also through a cadre of health workers who provide health education to the layers of society to remote villages. Besides, there is also a need for cooperation with the Office of Religious Affairs (KUA), because KUA is an official who is directly involved in the marriage process, so that with this collaboration KUA is expected to not only see from a legal perspective and someone's readiness in marriage but also be expected to understand the impact or the dangers of early marriage. The program implemented by the provincial Health Office is in line with the BKKBN program through several programs that are more focused on preparing adolescents' lives, including the Generation Planning program, Youth Counseling Information Center, Marriage Age Maturity. The programs carried out all provide education about adolescent reproductive health programs in which the core of this program is to prevent adolescents from avoiding drugs and also free sex which causes teens to have early marriages.

\section{Summary and Conclusion}

Based on the study, it can be concluded that early marriage causes physical and psychological impacts. Physically, early marriage causes women to experience bleeding during labor. Psychologically, young couples often quarrels that cause divorce, but the presence of children who make them continue to maintain the household, besides that early marriage also affects the family economy and education. Thus, the strategy to solve the problem of overcoming early marriage is to collaborate with the Office of Religious Affairs and coaching youth and families and the active role of all communities to better understand the dangers of early marriage, bearing in mind the impact of early marriage on physical and psychological young couples.

\section{References}

[1] Badan Pusat Statistik (BPS). (2017). Jumlah Penduduk Indonesia tahun 2017. https://www.bps.go.id/ diakses pada tanggal 15 Februari 2018.

[2] Badan Kependudukan dan Keluarga Berencana Nasional (BKKBN), "Gencar Kampanye Pendewasaan Usia Perkawinan,” 2011 [Online]. Available https://www.bkkbn.go.id/detailpost/ gencar-kampanyependewasaan-usia-perkawinan-kepala-bkkbn-resmikan-tugu-generasiberencana-di-tapin. [Accessed: Sept, 2019]

[3] Sekretariat Negara, Undang-Undang Republik Indonesia Nomor 1 Tahun 1974 tentang Perkawinan. Jakarta: Sekretariat Negara, 1974.

[4] A. Bachtiar, Menikahlah, Maka Engkau Akan Bahagia. Yogyakarta: Saujana Jogjakarta, 2004.

[5] Kemenkes RI, Riset Kesehatan Dasar; Riskesdas. Jakarta: Balitbang Kemenkes RI, 2013.

[6] B. Post, "Pernikahan Dini di Kalimantan Selatan," Banjarmasin Post, 2017. [Online]. Available: http://banjarmasin.tribunnews.com/2017/06/27/pernikahan-dini-di-kalsel-tertinggise-indonesia -palingbanyakusia- 15-19-tahun. [Accessed: Sept 2019]. 
R. Topan Aditya Rahman, Esti Yuandari.

The Correlation between Characteristics, Knowledge Early Marriage in Banjarmasin: The Impact on Reproductive Health and Prevention Strategy.

International Journal of Clinical Inventions and Medical Sciences, vol. 2, no. 1, pp. 15-19, March 2020. DOI: 10.36079/lamintang.ijcims-0201.77

[7] Yuandari, "Teenagers Premarital Sex Phenomenon in Banjarmasin,” 2017 [Online]. Available https://www.atlantis-press.com/proceedings/smichs-17/25886791. [Accessed: Sept, 2019]

[8] J. W. Creswell, Research Design: Qualitative and Quantitative Approaches. California: Sage Publications Inc, 2010.

[9] T. A. Rahman and E. Yuandari, Metodologi Penelitian dan Statistika. Bogor: Media, 2017.

[10] S. F. Rinaldi and B. Mujianto, Metodologi Penelitian dan Statistik. Pusat Pendidikan Sumber Daya Manusia Kesehatan. Jakarta: Kementerian Kesehatan Republik Indonesia, 2017. 